\title{
Glimpses of British Guiana at the Colonial and Indian Exhibition, 1886
}

\author{
Sara Albuquerque \\ IHC/CEHFCi, Universidade de Évora, Palácio do Vimioso. Largo do Marquês de Marialva, 8, 7000-554 Évora, Portugal. \\ e-mail: sma@uevora.pt
}

Submitted: 29 October 2014. Accepted: 11 January 2016

\begin{abstract}
This paper uses the example of the British Guiana Court at the Colonial and Indian Exhibition of 1886 as a case study to demonstrate how British Guiana (now Guyana) was represented in Britain at the time, by crossreferencing different materials (e.g. objects, correspondence, reports, and newspapers from that period). This exhibition also shows which raw materials from the British Guiana were of interest to Britain and the involvement of Royal Botanic Gardens, Kew in this matter. Nevertheless, the exhibition not only displayed objects and commodities, such as the case of sugar, but also displayed people. Here, particular attention is paid to the Amerindians who were portrayed as living ethnological exhibits at the exhibition. This paper aims to understand how British Guiana was seen and administered by its mother country and also how Everard im Thurn (1852-1932), the explorer, sought to manoeuvre that representation, as well as his relation with RBG, Kew. Taking into consideration that this colony was a neglected area of the British Empire, even in im Thurn's time, this exhibition was an opportunity not only to display the empire but also for advertising the potential of the neglected colony and to ensure that it would not be forgotten.
\end{abstract}

KEYWORDS: Anthropological Exhibits; Amerindians; Colonial Exhibition; British Empire; Everard im Thurn; Royal Botanic Gardens Kew; Guyana; Objects.

Citation / Cómo citar este artículo: Albuquerque, Sara (2016) "Glimpses of British Guiana at the Colonial and Indian Exhibition, 1886". Culture \& History Digital Journal, 5(1): e010. doi: http://dx.doi.org/10.3989/chdj.2016.010.

RESUMEN: Vislumbres de la Guayana Británica en la exposición colonial de 1886.- Este análisis se centra en la Exposición Colonial de 1886; a través del estudio de caso del Pabellón de la Guayana Británica (hoy Guyana), demuestra cómo ésta estaba representada en Gran Bretaña. Para mostrar sus contenidos cruza diferentes fuentes de la época: objetos, correspondencia, informes y periódicos. La exposición en aquel pabellón refleja que las materias primas de la Guayana Británica eran de interés para Gran Bretaña y la implicación en esta materia de los Jardines Reales Botánicos, llamados Kew. La exposición no sólo mostró los objetos y las materias primas, como el caso del azúcar, sino que también llevó habitantes de la Guayana. Aquí se presta especial atención a los amerindios que fueron retratados como "exposiciones etnológicas vivas". Este trabajo tiene como objetivo comprender cómo la Guayana Británica era vista y representada por su "madre patria" y también el papel del explorador Everard im Thurn (1852-1932) en la exposición. Teniendo en cuenta que esta colonia era un área descuidada por el Imperio Británico, incluso en tiempo de im Thurn, esta exposición fue una oportunidad no sólo para mostrar el imperio, sino también para dar publicidad de sus posibilidades y asegurar que no iban a olvidarse de él.

PALABRAS CLAVE: Exposiciones antropológicas; Amerindios; Exposición Colonial; Imperio Británico; Everard im Thurn; Jardines Reales Botánicos Kew; Guyana; Objetos.

Copyright: (C) 2016 CSIC. This is an open-access article distributed under the terms of the Creative Commons Attribution License (CC BY) Spain 3.0. 


\section{INTRODUCTION}

Britain was a major sponsor of international exhibitions along with other nations such as France, as this showcased their colonial power (Benedict, 1991). The Colonial and Indian Exhibition opened on the 4th of May 1886 and lasted for six months. This show case of imperial culture received over 5 million visitors (Mackenzie, 2008; Mathur, 2007b). Queen Victoria wished to capitalize on this exhibition hoping that it could act as a stimulus for industry, commerce and arts, thereby strengthening the bonds of the Union which existed throughout the Empire (Cundall, 1886 cit. by Levell, 2000). This Exhibition also provided the opportunity to sell and propagate the image of a vast and bountiful Empire, "Greater Britain", undivided under the rule of the almighty British sovereign, providing a context for the display of power/ knowledge (Bennett, 1988; Blanchard et al., 2008; Levell, 2000).

Much has been written on the Colonial and Indian Exhibition, however little attention has been paid to the particular case of the British Guiana Court (BGC). Part of it is probably due to the dispute between British Guiana and Venezuela and its relatively importance to the all of the empire. This might have played an important role in terms of what was written at the time, particularly in what regards to newspapers, and the importance given to the several objects exhibited. Some of these objects were preserved, others transformed and for some, unfortunately, nothing is known. Here, the role of the Royal Botanic Gardens, Kew (hereafter referred to as Kew) and Everard im Thurn (1852-1932), a British explorer, botanist, curator, photographer and colonial administrator, was crucial in terms of the preservation of some of these objects. Nevertheless, the information available (e.g. notes attached to objects, publications, reports) was on the one hand mostly disconnected between the different objects and on the other hand insufficient to generate an immersive experience: how were the objects displayed at the exhibition? Why were those objects chosen and not others? Here is where a powerful tool comes to place, one also adopted by Qureshi in her engaging book Peoples on Parade: Exhibitions, Empire, and Anthropology in Nineteenth-Century, in which the promotion and interpretation of ethnographic displays were examined by the author (Qureshi, 2011). Qureshi cross-referenced different materials connected to the $19^{\text {th }}$ century exhibitions with the information portrayed by the newspapers at the time. By doing so, one can not only have a picture of the official view through available reports, but also an insight into what kind of information was available to the general public.

By resourcing to this same approach, this paper addresses the Colonial and Indian Exhibition, and in particular its BGC, from a different perspective by focusing in particular objects, bridging the gap between technical reports, notes and the way the BGC was portrayed at the time by the Illustrated London News. Here the BGC will be analysed from the perspective of a selected set of its contents, linking them to the technical reports and notes, their whereabouts and history throughout the years and framing them in the context of that time. By doing this, it is intended to have an overview on British Guiana at that time through the Colonial Exhibition, as well as im Thurn's contribution in publicizing the colony.

This paper begins by analysing the way British Guiana was seen at the Colonial Exhibition through the BGC. In addition, im Thurn's contribution and involvement with Kew and the Exhibition will be exposed, as well as the reason of certain objects ending up at Kew. The role and contribution of the Royal Agricultural \& Commercial Society of British Guiana (RA\&CS) will be also taken into account.

The following section analyses the particular case of the "two magnificent squared trunks" on display at the entrance of the BGC, as well as the relation between im Thurn and Kew in this matter. In addition, the economic and medicinal importance of these botanical species, which the logs of timber belong to, will also be taken into consideration.

The third section analyses the products on display, as the case of sugar in British Guiana and the fourth section, analyses the objects on display, such as the Amerindian baskets at the Ethnological stand organised by im Thurn. Here, the explorer's role in order to preserve these same objects is examined.

The fifth section approaches the case of the "living objects" by using the reports of that time, a connection is established between these "ethnological exhibits" and their names, their human nature, thus deconstructing the idea of object to which they were related to. By doing so, this paper also intends to pay respect to the human beings displayed at the BGC.

The last section offers a snapshot of the BGC by cross-referencing the images from the Illustrated London News, newspapers of the time and official reports allowing the emergence of a powerful image: one where the BGC is brought back to life.

\section{BRITISH GUIANA SEEN TROUGH THE BGC}

The items displayed at the Colonial and Indian Exhibition can offer glimpses into Britain's interest at the time in certain resources from British Guiana. It is likely that the items on display were advertising certain products potentially important for the empire's economy, such as sugar and rum for instance. ${ }^{1}$ On the one hand, the way the objects were exhibited represented how British Guiana was seen at that time by Britain; on the other, the exhibits act as mirrors to the colonies by helping them to develop their own image (Benedict, 1991:5). What happened to all of the objects from this exhibition and how they were dispersed afterwards is difficult to know but it is known that many objects were sold (Rivière, 2010).

It is worth mentioning that the exhibition also had a pragmatic and commercial side. The products and objects on display at the exhibition provided a way of understanding what consumers in Europe wanted and did not 
want from the British colony (Hawtayne, 1887). That way it was possible to assess which products British Guiana could export.

In relation to the objects on display, im Thurn had a crucial role at the Exhibition since he was responsible for organising the ethnological collection at the BGC. According to The Illustrated London News "It was, doubtless, a pleasure to $\mathrm{Mr}$ im Thurn (...) to arrange the fine and varied ethnological collection exemplifying Indian manufacturers and the native mode of living." However, none of those ethnological items was sent to Kew, an institution which im Thurn had such a good relation with (J. R. J., 1887). Besides the logs of timber, which will be examined in this paper, Kew was presented with twenty-five selected specimens of native woods, a collection of cabinet making woods from Messrs. Park and Cunningham, and other products from the BGC such as fruits, seeds, barks, flowers and fibres (J. R. J., 1887). ${ }^{3}$ Kew was probably not presented with many more items from the BGC, particularly from the ethnological collection, simply because the Administrator-General of British Guiana and Executive Commissioner for the colony at the Exhibition was Mr G. H. Hawtayne, and not im Thurn himself. Im Thurn contributed with his collections to the Colonial and Indian Exhibition ${ }^{4}$ and he was always very keen to contribute specimens to Kew, which is evident in a letter of his to William Thiselton-Dyer. ${ }^{5}$ In addition, the reason why im Thurn was so interested to maintain a good relation with Kew, dates back to 1877 , when he was appointed curator of the Museum of the Royal Agricultural and Commercial Society of British Guiana, on Joseph Hooker's (1817-1911) recommendation, Kew's director and a very influential person at the time with many contacts around the world (Perkins, 1885: 522-534).

The newspaper The Times, besides a reference to the "little British Guiana Court", mentions im Thurn's contribution to the exhibition:

While the sugars and the fine woods of the colony will be prominent, there will be numerous other native products, including gold, and Mr im Thurn's ethnological figures will be of interest; natural history and native life will be amply represented". ${ }^{6}$

Regarding the gold referred to previously, it is important to stress that the colony had it on its Venezuelan border. Gold, which was known to exist in considerable quantities in this region, was precisely the main cause of the boundary dispute between British Guiana and Venezuela. As The Times noted, "Until the boundary question is settled nothing can be done to work it". ${ }^{7}$ Im Thurn, who was for many years linked to the exploration and development of British Guiana, was very knowledgeable of the border region. ${ }^{8}$ Considering im Thurn's awareness of British Guiana's situation, in 1899 the British Government appointed him expert witness at the Paris Negotiations on the Venezuela border dispute (Dalziell, 2002). Despite the fact that British Guiana had many resources such as gold and sugar, the British colony needed and wanted enterprise, capital and labour. Here lies the importance of the BGC at the Colonial and Indian Exhibition. The idea of advertising the colony aimed at attracting investment and encouraging people to live in British Guiana. ${ }^{9}$ This is where, the Royal Agricultural \& Commercial Society of British Guiana (RA\&CS), at the time in charge of the BGC, played a crucial role in discovering and exploiting the colony's resources (Hawtayne, 1884). Thus, besides discovering and exploiting British Guiana's resources, the Society also had to publicise the colony products through exhibitions and publications, mainly through the journal Timehri, founded by im Thurn in 1882 and dedicated to inform about the agricultural, commercial, scientific and literary subjects of British Guiana (Aspinall, 1933: 36-37). If the RA\&CS could know exactly what kinds of resources were exploitable, more people and investment could be attracted to the colony. British Guiana at the turn of the century had "an annual trade of at least five million sterling" making it an interesting investment ground both to the colonists and to the mother country. ${ }^{10}$ Despite the fact that the mother country seemed to forget the colony, im Thurn, during one of his visits to England, drew attention to the neglected colony. According to The Times, since Britain took over Guiana from the Dutch "it can hardly be said" that the colony had "made any progress at all." 11 Again, The Times refers to how British Guiana was forgotten and mentions how important it was to correct this situation, as the following extract indicates:

Somehow British Guiana seems shunted into a corner; we seldom hear much about it. This the colonists themselves feel. South America awaits a rich development, and it is good for us to have a solid footing there. Let us then do what we can to encourage the development of our colony and help the colonists to help themselves. ${ }^{12}$

One reason that may explain why British Guiana was neglected had to do with the border dispute with Venezuela. It is likely that the instability caused by this situation kept the colony as a low priority in terms of investment by the British Government. This was clearly reflected in the Colonial and Indian Exhibition, in which the small BGC did not have the same prevalence as other larger colonies. India for instance, was "Britain's biggest territory and asset" occupying pride of place at every exhibition (Dutta, 1997: 116). In the Colonial Exhibition, besides the Art Ware Courts, there were two other sections of the Indian Court dedicated to "economic products and the administrative and military arrangements of the British in India" (Dutta, 1997: 120). In addition, the Indian galleries re-created an Indian Palace, which British Guiana, obviously, could not compete with (Mathur, 2007a: 56).

Nevertheless, the way British Guiana was portrayed in the Colonial and Indian Exhibition meant to show a rich and diverse colony in terms of nature, culture and one with a wealth of resources which were worth being 
explored. This was achieved through the objects and products on display, such as the example of the magnificent trunks at the entrance of the BGC.

\section{"TWO MAGNIFICENT SQUARED TRUNKS"}

The report "Notes on Articles Contributed to the Museums of the Royal Gardens, Kew from the Colonial and Indian Exhibition, 1886" indicates which objects were donated to Kew (J. R. J., 1887). Kew benefited from many exhibitions of the empire, but this report shows that the 1886 Exhibition was a particularly valuable one. Kew's benefits were twofold: not only did it saw its collections enriched with a great number of specimens, but these specimens bared an intrinsic value attached by their particularity and rarity. In relation to im Thurn's involvement with the exhibition and in particular the BGC, the same report mentions that "the most striking exhibits obtained from this Colony [British Guiana] were the two magnificent squared trunks, most liberally purchased and presented to the Royal Gardens by Everard im Thurn" (J. R. J., 1887: 4-21). Furthermore, in one of im Thurn's letters to Sir William Thiselton-Dyer, he wrote the following:

\begin{abstract}
As regards the logs of timber, I am sorry that you should have had such unpleasant transactions with Hawtayne about them. He is an excellent fellow, but in some way very mysterious to me, has succeeded in (...) almost everyone with whom he had Exhibition dealings. It was kind of you [Sir William Thiselton-Dyer] to offer to pay me for the logs, but I had made up my mind to present them, and so I shall be gratified if the Kew authorities will regard them as gift from me. ${ }^{13}$
\end{abstract}

The extract from this letter, besides demonstrating the misunderstanding between Sir William Thiselton-Dyer and $\mathrm{Mr} \mathrm{G}$. H. Hawtayne - the Executive Commissioner for the colony at the Exhibition of 1886, who wanted to sell the trunks to Kew- also reveals im Thurn's involvement with the botanical institution at the time.

On another occasion im Thurn apologises for what seems to be a misunderstanding with Joseph Hooker. ${ }^{14}$ In the third volume of Timehri, im Thurn mentions in his note entitled "A Difficulty of Botanical Collectors", how complicated it is, besides collecting, to name the plants considering that in British Guiana they do not have the time or the necessary resources to proceed with the identifications (J. R. J., 1887: 4-21). Im Thurn also adds that, for this reason, the plant specimens are sent to institutions such as Kew Gardens, which according to the Timehri editor, means that:

The scientific men employed, despite their ability and zeal, are unable to cope with the abundant material forwarded to them from all parts of the world; and they therefore deal with certain plants, those belonging to genera in which any of the scientific workmen concerned feel some special interest; but all the other plants are simply drafted, labelled with the name of their dis- coverer and the place and date of their discovery, but without any critical examination, into what appears to be their approximate place in the herbarium, there to lie until, perchance in a few cases, some new specialist interested in their particular genera may examine them (im Thurn, 1884: 162).

Im Thurn continues and explains how it is terrible that at Kew, they put together perfectly distinct plants that can "only be appreciated, and fittingly lamented, by one who knows the plants to which reference is made in their natural state" (im Thurn, 1884: 163). Kew's Director was understandably offended after the publication of this note. As im Thurn had Hooker's support to go to British Guiana, it was in the former's interest to maintain a good relationship and connection with Kew Gardens. For this reason im Thurn retracted himself in one of his letters, regarding what he considered an "objectionable passage". He assured Hooker that he did not intend to offend him and acknowledged that he owed much gratitude to Kew. ${ }^{15}$ Im Thurn continues to explain that his "comments concerning the practicalities of collecting and identifying plants were intended to express the difficulty of collecting multiple examples of specimens for the purpose of identification". He adds that the situation should be clarified in the following issue of Timehri. ${ }^{16}$ The clarification happened in volume four (im Thurn, 1885). In this issue im Thurn states that "the offending paragraph was therefore in no way intended as a slur on the Kew staff; but rather it was intended to indicate, as a difficulty felt by some botanical collectors, that in cases where perhaps but one species of an obscure family or genus was included in a collection" (im Thurn, 1885: 133). From these two examples it is evident that im Thurn was making an effort to maintain a good relationship with Kew and its staff.

One of the reports about the articles sent to Kew from the Colonial and Indian Exhibition 1886, mentioned two magnificent squared trunks and the fact that the entrance would be remembered for its size and magnificence (J. R. J., 1887). The squared trunks were from greenheart (Nectandra rodioei R.H. Schomb. Lauraceae family) and mora (Mora excelsa Benth. Moraceae family) (J. R. J., 1887; Missouri Botanical Garden, 2011a). ${ }^{17}$ These trunks "stood at the entrance to the British Guiana Court of the Colonial and Indian Exhibition, and measured some 28 feet [around 8.5 metres] in length" (J. R. J., 1887). Apparently, there were two very similar entrances to the BGC, north and south respectively, as the illustrations below demonstrate (Fig. 1 and 2).Besides the logs previously mentioned, there were another two wood logs in the other entrance, but from different species: siruaballi (Oreodaphne Nees \& Mart. Lauraceae) and suradanni (Anonymous, 1886a). ${ }^{18}$ A newspaper confirms this, as it mentions "the massive gateway of great logs of mora, greenheart, siruaballi and sirudanni, four leading economic woods of British Guiana." 19 The Illustrated London News also referred to "the wealth of British Guiana in timber by the massive beams of the brown cirouaballi and deep red saradani, which form the entrance to the little court." 20 
The references to the size of the trunks and the prominent way they were on display at the entrance of the BGC so that "it will be remembered" demonstrates not only power and wealth, but also the importance of these two species in British Guiana and their economic importance (J. R. J., 1887). It also reflects, in a certain way, the ascendance of British commercial influence, as well as the amount of investment and trade in South America during this period (Aguirre, 2004: xiii-xxix).

With such vast richness in terms of flora, why were these particular species chosen? Presumably because those species had not only an obvious economic value, but also medicinal properties that could contribute to progress in science - for example, in terms of the study of chemical properties. By examining the uses and properties of one species in particular, Nectandra rodioei, this scenario becomes clearer.

$N$. rodioei, also known as greenheart, is one of the tallest forest trees of British Guiana and considered to be one of the best timbers of the colony (Hawtayne, 1886; J. R. J., 1887). ${ }^{21}$ Hawtayne described it as being "unsurpassed by any other wood in the colony" (Haw-

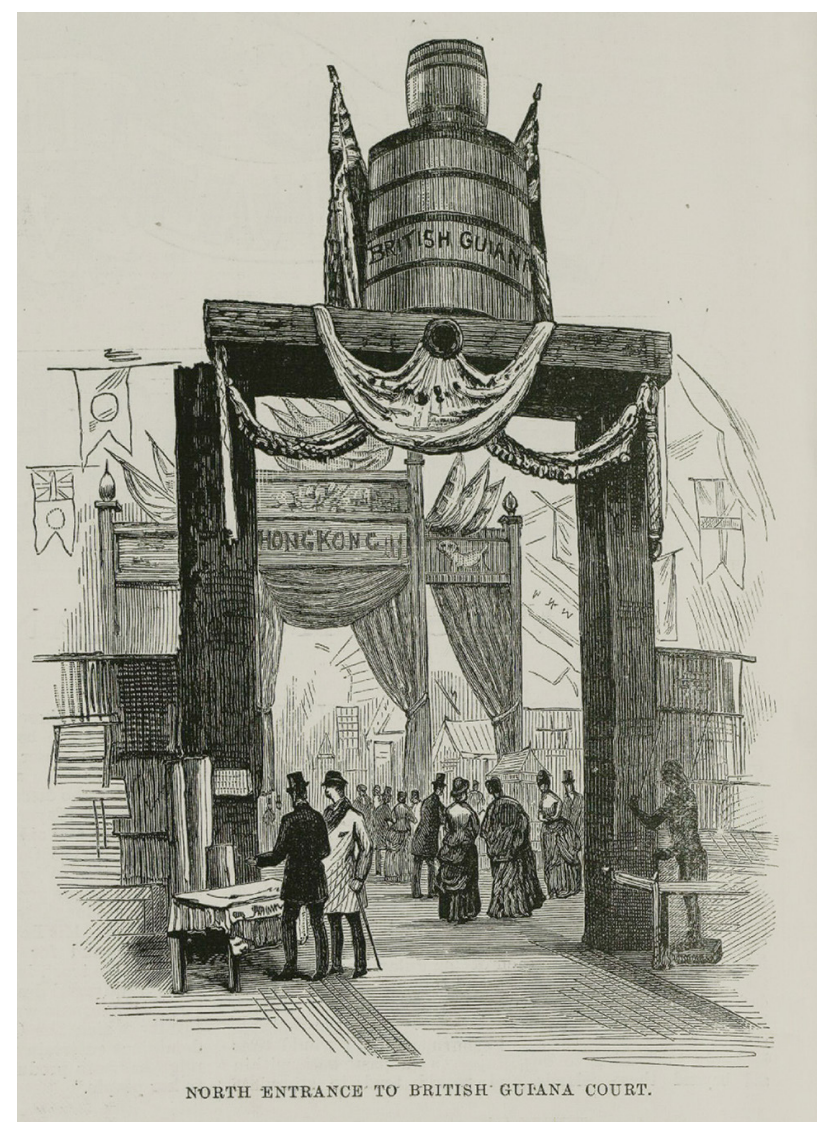

FIgURE 1. Engraving from The Illustrated London News (1886: 338) "North Entrance to British Guiana Court". The containers represented in the picture are vats made of wood that were used "for collecting rain water from the roofs of houses in the colony." 51 tayne, 1886; J. R. J., 1887). Its wood is one of the most durable and it was used for house framing, mill timbers and wharves (J. R. J., 1887: 4-21). Nonetheless, the demand for this particular wood was so great that the careless cutting down of young trees made good greenheart difficult to procure as it was considered one of the eight first-class woods according to The Times. ${ }^{22}$ In terms of greenheart's medicinal properties, its bark and seeds were a source of beeberine, which is an alkaloid that can be used as a tonic, febrifuge and a substitute for quinine (Anonymous, 1886a; Hawtayne, 1886; J. R. J., 1887). The seeds were also used by the Amerindians to cure diarrhoea. In times of scarcity they were ground and mixed with other meals (Hawtayne, 1887: 24). Im Thurn sent a sample of this starch to Kew in 1879 with a note attached, which indicates that it was mixed with cassava - the basis of the Amerindian diet. ${ }^{23}$ Apparently, the greenheart seeds are used nowadays in Guyana as an abortificient and the Makushi women take them as a tea for this purpose. ${ }^{24}$

The species Mora excelsa is a hard and heavy wood, and young mora trunks are usually preferred for house posts because of their heaviness and strength (van Andel, 2000: 171). This species is also used to build canoes, which can last for up to twenty years. When old, this wood can be used as a board for cassava grating. Besides this, in some Carib communities the hollowedout mora trunk is used as a drinking vessel for alcoholic drinks, such as paiwari and cassiri. These cassiri canoes, as van Andel described them, can contain 100 litres of drink. The mora is also used in wooden constructions to attach matapies, a long Amerindian basket which is used to extract the poisonous juice of the cassava. In terms of Mora excelsa's medicinal purposes, its bark (containing eight percent of tannins) when boiled and made into a tea, is used to relieve diarrhoea and dysentery (van Andel, 2000: 171).

So what happened to the "magnificent trunks"? After the closure of the timber Museum (Museum No.III) at Royal Botanic Gardens, Kew at the end of the 1950s - that led to its conversion into an Orangery - the collection was reduced with many specimens distributed to other institutions and others converted into planks (Anonymous, 1960). ${ }^{25}$ The timber "specimens of special ethnographical interest" were sent to different institutions such as the Horniman Museum making it "possible to exhibit about two hundred and twenty different commercial woods in the space available" at Kew (Anonymous, 1960: 1-28). It is likely that the two trunks were on display at Museum No. III, and later on, when the Orangery closed, the mora and the greenheart blocks were converted into planks to reduce the space they were taking.

The Economic Botany Collections at Kew still hold the woods which im Thurn presented although the logs mentioned here are now no longer "two magnificent squared trunks", as they have been reduced to two small blocks of wood. However, besides timber there were other important commodities, such as sugar that were also on display. 


\section{PRODUCTS ON DISPLAY: THE CASE OF SUGAR}

Regarding other objects on display at the BGC, behind the Amerindian model at the South Entrance (Fig. 2) one can see what seems to be a stand with glass bottles which probably contained sugar and saccharine products such as rum and syrups or even gums and oils since these were the most common goods produced at the colony.

As the Official Catalogue notes, there were many sugar specimens on exhibit, including muscovado, white and yellow crystals, and dark sugar (Anonymous, 1886a). As sugar was "the chief product" the Official Catalogue mentions that on its success depended "the prosperity if not the existence of the Colony [British Guiana]", it is therefore understandable why the BGC dedicated a section to sugar (Anonymous, 1886a). In addition, the following extract from The Times confirms its importance:

Mr. Hawtayne, the energetic Commissioner for British Guiana, has been too modest in his demands for space; his small but highly interesting court (...) has a somewhat overcrowded appearance. Sugar and rum, in every variety of colour and strength, are the most conspicuous objects in the court, as they are the most important articles produced by the colony. ${ }^{26}$

However, although sugar was an important commodity in the colony and the British Guiana sugar factories were "among the finest in the world", its exports were al- ready decreasing by the time of the exhibition. According to The Times, the severe crisis that British Guiana was passing through was caused by the production of beet sugar by Germany and other countries, which offered better prices. ${ }^{27}$ Apparently, all other colonies that depended on sugar, just as British Guiana, also suffered greatly. In British Guiana, apart from sugar, few other commodities were there to be exploited by the colonist. ${ }^{28}$ Nevertheless, this crisis was not reflected in the BGC. Here, different samples of this commodity embraced all the different classes of sugar manufactured in the colony and it was believed that $70 \mathrm{lb}$ (ca. $32 \mathrm{~kg}$ ) of sugar was being sold per day in the colony court. ${ }^{29}$

In order to respond to the sugar crisis, according to The Times, the colony was encouraged to invest in other commodities such as coffee and cocoa, and to develop some of the fine fibres such as silk grass and tibisiri, balata gum or even tanning barks, that were also on display in the exhibition. ${ }^{30}$ Some of these fibres were used to make various baskets, such as warishis and matapies, produced by the Amerindians in British Guiana.

\section{OBJECTS ON DISPLAY: AMONG THE WARISHIS AND MATAPIES}

The BGC presented an image of the colony of richness and diversity but there is more than meets the eye once we look past the displayed objects and raw materi-

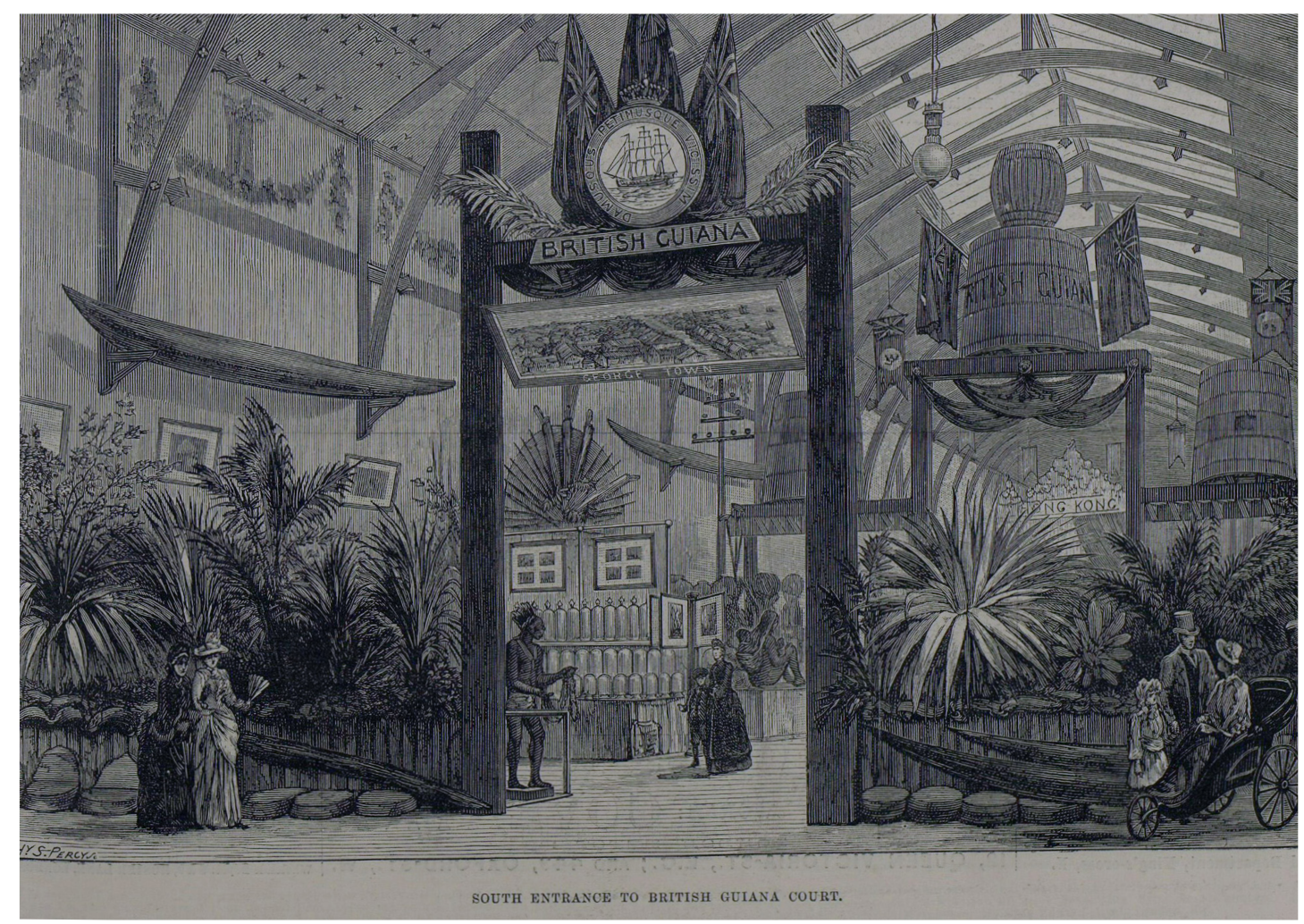

Figure 2. Engraving from The Illustrated London News (1886: 341) "South Entrance to British Guiana Court". 
als. Although small, the BGC was nevertheless very rich in ethnological artefacts.

The collections illustrative of native ethnology and life are full of interest; the models of Indian houses, hammocks, pottery, basket-work, graters and other utensils for preparing cassava (the Guiana Indian staff of life), fire-sticks, various articles of dress and ornament, the warrior shield used in wrestling, the macquarrie whips, smart enough to draw blood, though apparently only of grass, and used in a game played by two Indians to try each other's strength, bows and arrows, clubs, drums all these and many other similar objects have a real educational value, and show the advantage of having the help of a specialist like Mr im Thurn in arranging a court like that of British Guiana. ${ }^{31}$

This richness in terms of artefacts is evident from the illustration of the Ethnological stand (Fig. 3). Here, a model of an Amerindian woman carrying a baby with the help of a suriana — a basket used "for carrying burdens on the back" as described by im Thurn ${ }^{32}$ is exhibited. The suriana, also known as warishi nowadays, has a strong band made of natural fibres, which is typically passed over the top of the head (Roth, 1924: 375).

A more detailed warishi is shown just next to the model and is full of items that are probably calabashes. Adjacent to the warishi are more baskets, swifters and pots, such as a pepper pot and goglet. Although it is difficult to know what subsequently happened to the items on display, similar $w a-$ rishi baskets were sent to Kew by im Thurn and later on, in 1960, offered to the British Museum. The Amerindians still use these baskets to carry cassava, wood and even babies. Im Thurn sent different kinds of baskets to Britain and many of them were used to pack different objects. ${ }^{33}$ The way these baskets are produced is explained in Walter Edmund Roth's work entitled An Introductory Study of the Arts, Crafts, and Customs of the Guiana Indians, which describes the preparation and splitting of the stems of itiriti plant in detail (Roth, 1924: 138-139). Roth also observes that during this process the "inner side of the nail of the left forefinger" is used as a wedge, so the expert basket makers are easily identified because their nail is often chronically damaged (Roth, 1924: 138-139).

All the baskets mentioned previously were, and still are, being produced by Amerindian men, so that the women can have the utensils needed to prepare cassava and hammocks, such as cotton baskets, warishis to carry cassava, and matapies to squeeze the poison juice from the grated cassava. While men are responsible for the basketry, women are responsible for the production of the cassava bread, farine and hammocks. ${ }^{34}$ The matapie is a very distinctive object, which is illustrated at the Ethnological Stand (Fig. 3). A matapie is a long basket hanging by a horizontal stick (Fig. 4).

This particular basket not only plays a major role in the daily life of the Amerindians — as im Thurn described, "no

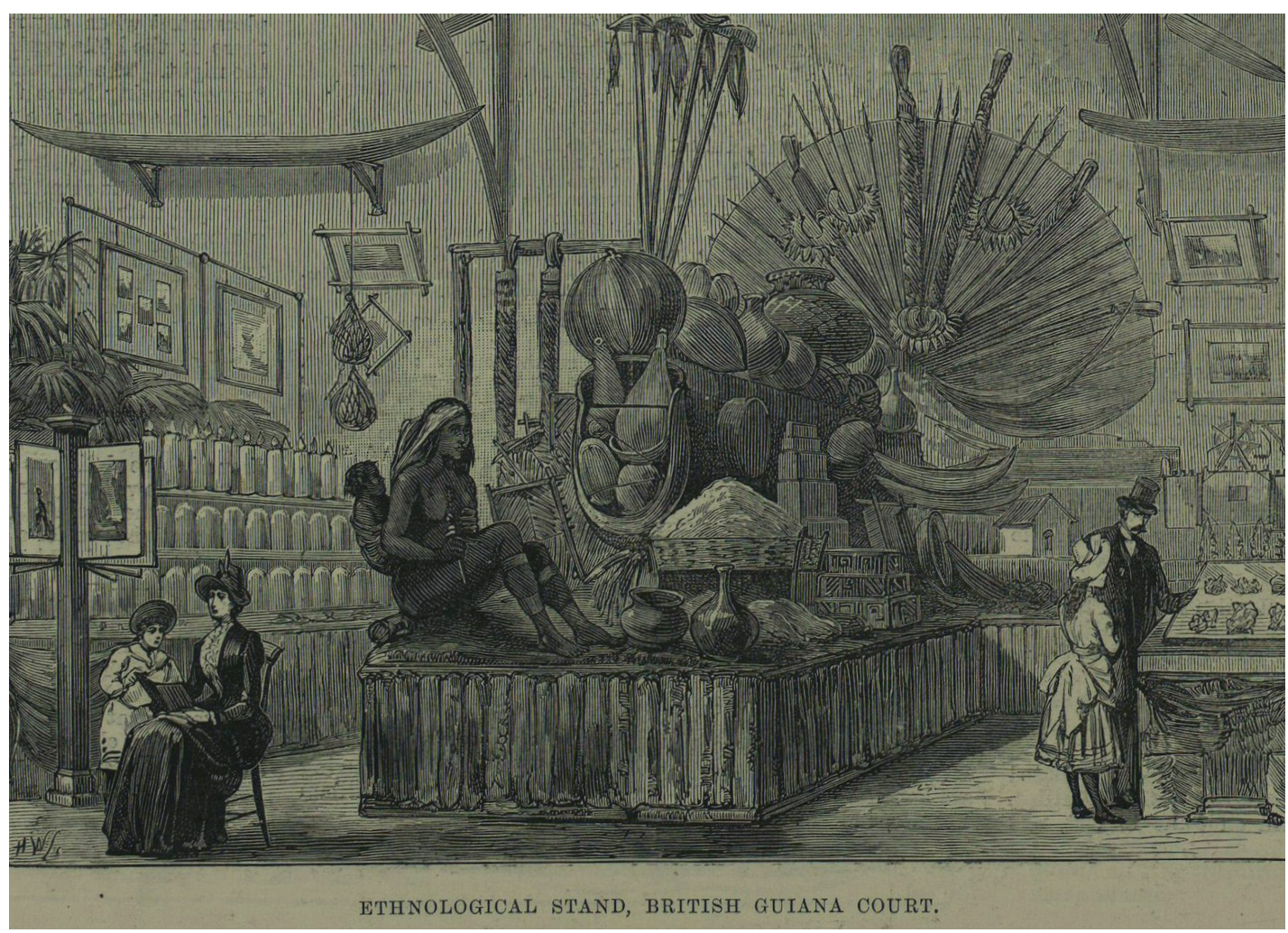

Figure 3. Engraving from The Illustrated London News (1886: 340) "Ethnological Stand, British Guiana Court". 
scene is more characteristic of Indian life than that of the women preparing cassava"- but also materialises an amazing richness in terms of Amerindian traditions and histories (im Thurn, 1883: 260). The matapie is also known as tingi in Makushi which means "similar to an anaconda". This name comes from a very old Amerindian story that is still told nowadays. In this story, a man while seeing an anaconda (also known by the Makushi as comodi) swallowing an agouti (a mammal) thought he could reproduce the same principle by using mukro (Ischnosiphon arouma (Aubl.) Koernicke) in order to squeeze the cassava and take the poisonous juice out of it. ${ }^{35}$ Not only is the shape of the matapie similar to an anaconda, but the movements the snake makes when swallowing the animal are similar to the ones made by Amerindian people when they are squeezing the cassava to remove the poisonous juice. ${ }^{36}$ Once dried, the cassava is ready to be used for making bread or flour. For this purpose "a large circular iron griddle or plate" is placed over the fire and the bread baked on it (im Thurn, 1883: 261). Although this is a very traditional Amerindian process, some changes to the method have occurred over time because of cultural encounters. As an example, im Thurn mentioned that the "large circular iron griddle or plate" was from "European manufacture" but the "remote Indians" used a flat slab of stone for the same purpose, although there "can be little doubt that this stone was originally universally used" (im Thurn, 1883: 262).

Im Thurn was fascinated with the Amerindian way of processing cassava, stating in his book that he even tried to imitate the Amerindians: "I have often admired, and vainly tried to imitate, the skill with which an Indian woman 'quoits' up these large and thin [cassava] cakes" (im Thurn, 1883: 262).

Im Thurn was not only fascinated with the Amerindian objects, but was also concerned with their disappearance because of the influence of the "white men", as the following quote attests:

Indian basket-work is so beautifully neat, that it is much to be regretted that the art of producing it is fast dying out, at least wherever the influence of white men is felt. Missionaries would certainly be doing good work if they endeavoured to revive and retain this and all other such native arts (im Thurn, 1883: 262).

Besides his preoccupation, he also suggests possible ways to avoid the extinction of Indian basket-work skills,

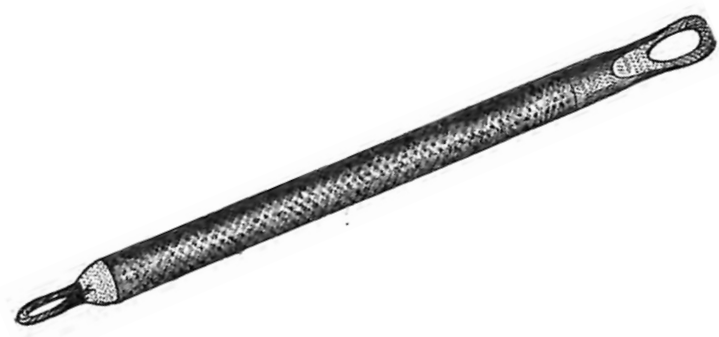

FIGURE 4. Engraving from Among the Indians of Guiana (im Thurn, 1883: 261) "Cassava squeezer" or matapie. especially by active participation of the missionaries in maintaining the Amerindian crafts. These missionaries, however, as "agents of colonialism", to use Renato Rosaldo's expression, were the same agents that opened the way for the "effect of civilization" in the contact between Amerindians and Europeans (Gruber, 1970; Rosaldo, 1989). In addition, there is also a certain contradiction when im Thurn refers to the "influence of white men". Besides being a "white man" himself, im Thurn was also shaping and changing the culture around him by obtaining certain Amerindian objects and giving beads as an exchange, for instance. This nostalgia in im Thurn's discourse "occurs alongside [with] a peculiar sense of mission, the white man's burden, where civilized nations stand duty-bound to uplift so-called savage ones", as Rosaldo puts it (Rosaldo, 1989: 108). Therefore, it was important to "record the precious culture before it [could] disappear forever"(Rosaldo, 1989: 115).

In addition, as Burton Benedict observes, "Artefacts alone can create an impression of a culture". Therefore, the items exhibited not only represented the objects "of those who had been conquered and colonised" but also gave an impression of how Britain saw and represented its colony through the objects on display (Benedict, 1994). Nevertheless, it is important to keep in mind that these objects were taken away from their original contexts and "arranged in patterns at international and colonial exhibitions”(Benedict, 1994).

\section{“LIVING ETHNOLOGICAL EXHIBITS"}

"There are important differences between exhibiting objects and exhibiting people. Objects don't talk back" (Benedict, 1991: 5-9).

The world exhibitions in the nineteenth century represented the "dominant relations of power" in which different societies were categorised, rationalised and objectified (Çelik \& Kinney, 1990). The result of this categorisation created a hierarchy in which the "portrayed world" was defined by "races, sexes, and nations" that occupied specific and fixed places in these exhibitions by the host countries (Çelik \& Kinney, 1990: 36). The way non-Western cultures were represented at these exhibitions was defined by the host culture, which in the case of the Colonial and Indian Exhibition of 1886 was Britain (Çelik \& Kinney 1990: 36). These powerful exhibitions were visually appealing and educational, instead of being just "pictorial, literary or journalistic" (Çelik \& Kinney, 1990: 37). According to Tony Bennett, the exhibitions played "a pivotal role in the formation of the modern state and are fundamental to its conception" working as a an "educative and civilizing" agency (Bennett, 1988: 79). By doing this, these exhibitions "created a powerful stock of images of the non-Western world for European consumption" where all sorts of entertainments were used to attract the public (Mathur, 2000; Benedict, 1991: 5-9). Moreover, the exhibitions also reflected a "cross-cultural character" where the "indigenous cultures" of the British Empire were displayed. An example of this was the visit 
to the queen by the "indigenous people" that will be discussed below (Çelik \& Kinney, 1990: 38).

The British Guiana House, where the Amerindians from British Guiana were seen as "living ethnological exhibits", was part of the British Guiana representation at the Colonial and Indian Exhibition 1886 (Fig. 5). ${ }^{37}$

The purpose of this British Guiana House was to give a sense of the Amerindian way of life, so besides exhibiting Amerindian objects, the "natives" were also included as "living ethnological displays" (Fig. 6) (Mathur, 2000: 492). The practice of bringing people from overseas to world exhibitions started in Paris in 1867. This aspect was addressed in an extraordinary exhibition which took place at the Quai de Branly Museum in Paris in 2011, entitled Exhibitions. L'invention du savage which resulted in an impressive catalogue (Blanchard u. a., 2011). As John Mackenzie suggests, these "native villages" "were the prime way in which people in the metropolis were brought into contact with the conquered peoples of the Empire" (Mackenzie, 2008: 265). In the case of Britain, the practice to amalgamate its colonised peoples into the exhibitions began with the Colonial and Indian Exhibition of 1886 , which had ninety-seven people on show, including the Amerindians from British Guiana (Benedict, 1994). Moreover, for these exhibitions the natives not only helped to construct the Indigenous villages, but later on were to inhabit them, displaying their arts and crafts, which was very popular at the time (Benedict, 1991).

The display of living exhibits not only intended to show the extension and glory of the British Empire, but also to provide an "antithetical sense" (Çelik \& Kinney, 1990: 38). The idea was to demonstrate the relative advancement and superiority of the colonial power by comparing "the primitive", represented by the Indigenous people, and the industrialised nations (Çelik \& Kinney, 1990: 38). The representation of "primitive peoples" was also to show them as "still-living examples of the earliest stage in human development" denying any existing history of their own (Bennett, 1988: 92). This led to an "increasing interest in the diversity of human morphology, stimulated by discoveries of new countries and colonial conquests". Thus, there was an urgent need for anthropologists to explain this diversity (Blanchard u. a., 2008). In "Ethnological Encounters", Michael Bravo explores the subject of Ethnology, which will be addressed shortly in the following paragraph (Bravo, 1996: 339). While European culture had a long tradition and practice of recording descriptions of other peoples in a systematic way, argues Bravo, the terms "ethnology", "ethnographic" and "ethnological" were only introduced in the 1830s and 1840s (Bravo, 1996: 339). In Ethnology, differences in language and vocabulary were analysed taking into consideration both the diversity and the similarities. Questions like "whether the different human races belonged to the same species" remained unanswered for most of the century (Bravo, 1996: 338). To conduct valid ethnological research it was required access to information about the peoples of other nations (i.e, their history, beliefs, language, customs and culture) (Bravo, 1996: 342). However, this had to come from reliable sources from all different parts of the world, especially where the British had political and economic interest. Cultural artefacts were used in these studies but so were "live specimens", who "were first studied in their natural environment" and later on transported and exhibited (Blanchard et al., 2008: 3).

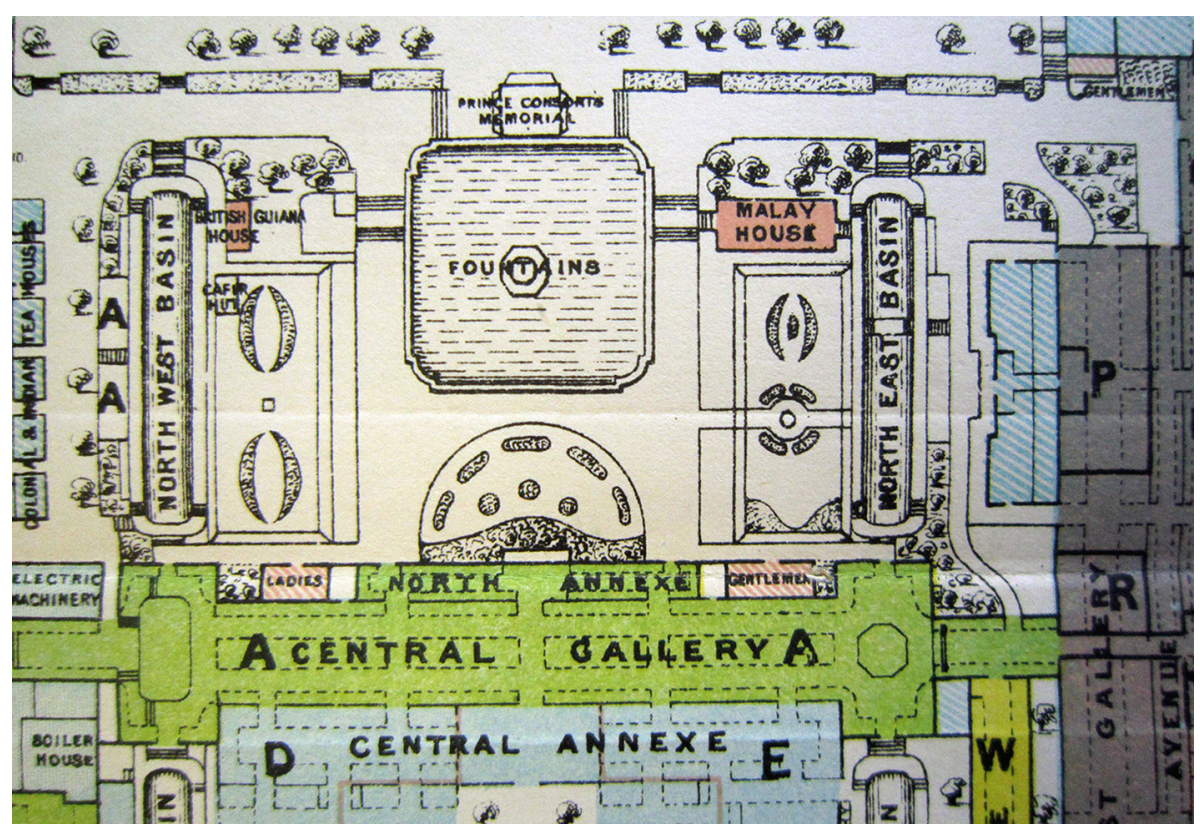

Figure 5. Detail of the ground plan of the Colonial and Indian Exhibition Site, South Kensington, 1886, in which the British Guiana House and the British Guiana Court (R) are pictured (Anonymous, 1886a). 


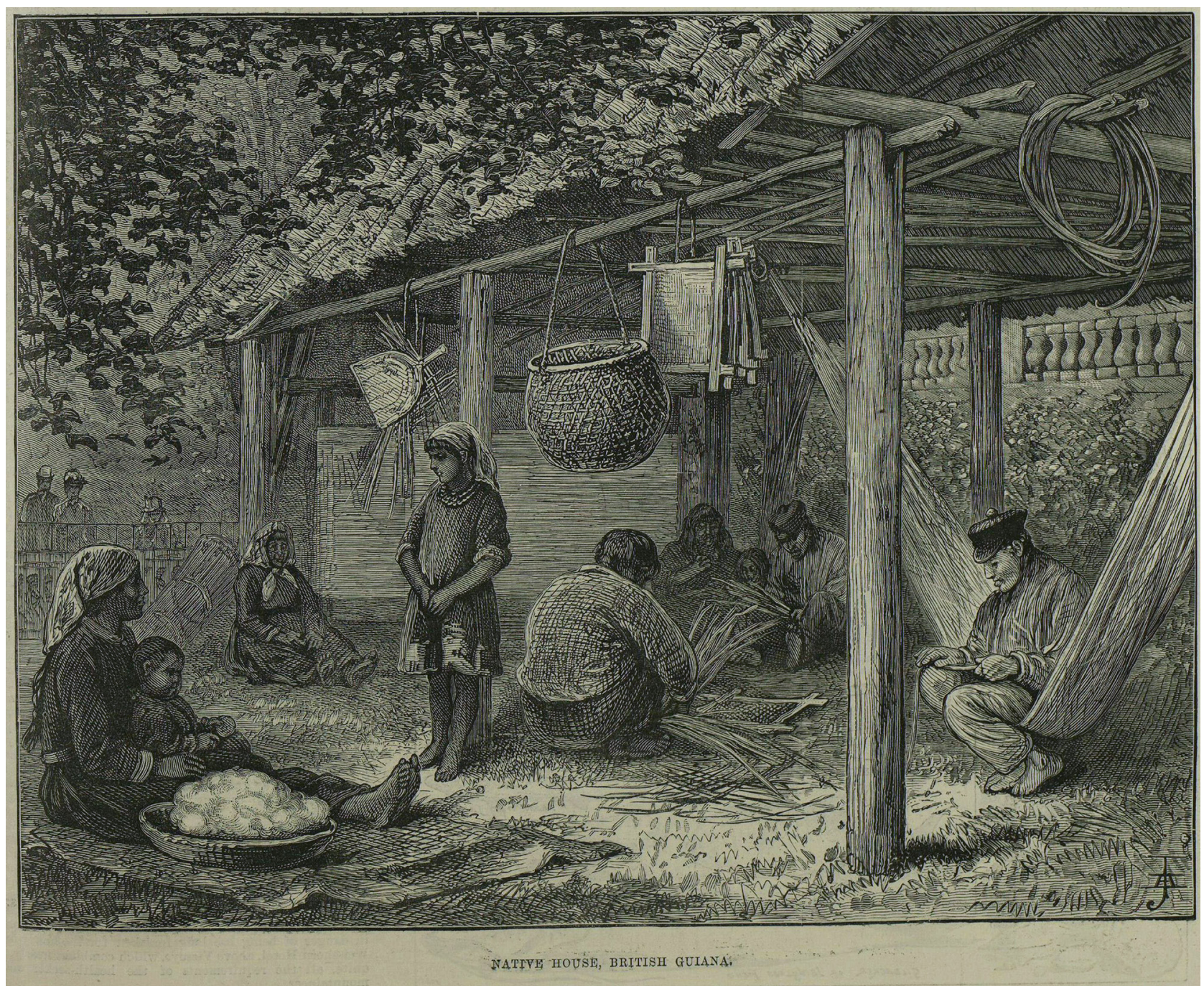

Figure 6. Engraving from The Illustrated London News (1886: 337) "Native House, British Guiana".

"Indigenous peoples were displayed and seen as objects of natural history in Victorian exhibitions" (Bravo, 1996: 338; Blanchard et al., 2008: 3).

Britain's Great Exhibitions gradually became dominated by the theme of the empire, building on the combination of education, trade fair and entertainment on a huge scale (Mackenzie, 2008: 259). The way the "Other" was exhibited, not only showed the curiosity for the "Other", the different and exotic, but also reinforced the idea of inferiority and the primitive, by reflecting the "attitudes and policies of the colonising powers" (Blanchard et al., 2008: 4; Benedict, 1991: 7). On the other hand, the "living exhibits" also had the function of amusing, informing and educating, although the boundaries were not very clear, and the interests were various (Blanchard et al., 2008: 24). The "entertainment value of the 'savage' was increased" by activities such as dance, music and games which were considered primitive (Blanchard et al., 2008: 25). It is important to stress that there was not only a spatial distance but also a tem- poral distance between the "living exhibits" and the exhibition visitors. As Johannes Fabian notes, Anthropology, an emerging discipline at the time, was inclined to assume a "petrified relation" between the observer and other societies (Fabian, 1983). Therefore, Indigenous societies and their histories were understood as fixed and unchanging (Fabian, 1983: 143). How the "natives" performed their artisanal tasks seemed to be part of a distant past, giving an idea of their apparently undeveloped status (Çelik \& Kinney, 1990: 39). This is demonstrated in the illustration in The Illustrated London News (Fig. 6) that shows the Amerindians performing some of their daily activities: producing baskets, preparing the cotton to create hammocks or just simply observing and talking to each other. The objects on display are very typical as well: fans, quakes, cassava swifters and a hammock. This illustration in one sense could seem an image from British Guiana. The way the objects were displayed gives a sense of an Amerindian scene, were it not for the fact that the Amerindians were so heavily 
dressed, the marble wall behind the house and the two curious visitors looked so out of place.

The image of the British Guiana house (Fig. 6) also shows a fence that keeps a certain distance between the Amerindians and the visitors. As Benedict says, "In many exhibits people were treated as objects and not given the opportunity to talk back" (Benedict, 1991). This is demonstrated by the way they were kept back from the public by a fence (Benedict, 1991: 8). The space of representation clearly reveals the opposition between the public "the white citizenries of the imperialist powers", and the "primitive otherness of conquered peoples" both separated by a fence (Bennett, 1988: 92). The fence also emphasizes that is a need to contain and keep under control what lies behind the barriers (Wintle, 2009). In addition, many Indigenous people just spoke unrecognised languages, which helped to keep a social distance (Benedict, 1991: 8). However, in the case of these particular Amerindians, some could speak, read and write in English (Anonymous, 1886b). Besides, all had "been baptized in the Church of England Mission" and had "British" names, which gave the impression that the Amerindians "on display" were "civilised Indians", as described by im Thurn in his book, the Amerindians that were "civilised" were the ones that could speak besides their native language, another western language (Anonymous, 1886b: 313; im Thurn, 1883: 45).

In short, as Benedict observes, the ways of displaying people and their artefacts in the colonial exhibitions could be summarise in three different approaches: they could be seen as merely curiosities, trophies or as artisans displaying their products (Benedict, 1994: 29). Regarding the display of people with their artefacts, the objects shown were unusual to the audience, as were the activities performed.

One of the newspapers notes the interest the Amerindians aroused:

[The Amerindians] have a little shelter for themselves in the space near the fountains, and it is interesting to watch them quietly pursuing their occupations, weaving in primitive fashion, making spear-heads, and so on. We had the pleasure of seeing one of them, a vigorous-looking young fellow, shooting an arrow from the blowpipe, an extremely difficult operation. The precision of aim and the distance to which the arrow was sent were wonderful. ${ }^{38}$

However, although much has been written about the "living anthropological exhibits", little attention has been paid to the ethnological exhibit at the British Guiana House.

Through the newspapers of the time it is possible to have glimpses of how the Amerindians were seen during the exhibition and the reception at Windsor Castle, where the queen invited the "natives" for lunch, as the following extracts attest:

The Queen received today the natives of her Majesty's dominions who have come to England to take part in the
Colonial and Indian Exhibition; The natives of British Guiana played on instruments and showed the use of their arms. ${ }^{39}$

Besides this particular occasion where the Amerindians were hosted by the queen and exhibited their arts, few newspapers mentioned the "Indians from British Guiana" but when this happened, they were compared with the Amerindian models on display at the colony court:

In the British Guiana Court, Mr Hawtayne, (...) had the honour of presenting again to the Queen the interesting natives of that colony, who have quite recently been brought over. ${ }^{40}$

Real live specimens of aboriginal natives, not to mention the fine models which grace several of the courts, as those of India and British Guiana. ${ }^{41}$

[The Amerindian models when] compared with the live specimens of natives recently imported they seem somewhat idealized, though probably they belong to different tribes. The three couples and the piccaninnies [small black children] belong, we understand, to two tribes, the Macoosis and Aracoonas, and are Christianized. ${ }^{42}$

In The Illustrated London News, the Amerindians were mentioned in only a few lines noting what they were wearing at the exhibition and what they wear "ordinarily" in British Guiana:

The natives who keep watch and ward at the southern end are in fête costume. Ordinarily, all the clothing worn by the Indians is a waist-cloth by the men, and a small bead apron by the women. ${ }^{43}$

The above extracts also highlight how the Amerindians are referred to as "real live specimens of aboriginal natives" that had been "recently imported", which demonstrates how much they were seen as objects. However, despite the extracts from the newspapers describing the Amerindians as specimens, it is still possible to unveil the human beings behind these portraits and descriptions. To do this, an attempt is made to connect the Amerindians pictured and the names listed in the table of the Report of the Colonial and Indian Exhibition (Fig. 7 and Table 1) (Anonymous, 1886b: 313). According to this report, which lists their names, activities and ages, at least three Amerindian families represented the "Red Indians of British Guiana" at the British Guiana House: Austin's, Dance's and Mathews's/Gordon's (Anonymous, 1886b: 313). The three families are also referred to as "three couples" who were "Macoosis", "Aracoonas" and, according to the report, "Acawoios." "44 The Times mentioned that there were ten Amerindians who actually visited the queen, who are listed in the report, but only nine are pictured in the illustration. ${ }^{45}$ Following this list, it is tempting to try to identify the people in the picture. However, there are only nine Amerindian people represented so the identifications 
made are no more than mere possibilities (Fig. 7). It is difficult to imagine what these families had been through, leaving their villages in the interior of tropical British Guiana, which they had perhaps never left before, and travelling by ship to cold Britain. In Britain, these Amerindians probably not only suffered with the weather but were also certainly astonished with London, the buildings and Londoners. Maybe being with the queen at Windsor Castle was not such an occasion for them as it would have been for British people. Nevertheless, being "displayed" at the British Guiana House was probably a very uncomfortable experience for the Amerindians. Although they were performing their daily life activities, this time they were confined to a minor and artificial space in comparison with the savannahs and rainforests they were used to.

The naming of the Amerindians who were represented in the image of the Illustrated London News as "ethnological exhibits" seeks to see them not as objects but as people with an identity. By using the reports of that time, it is still possible to connect these "ethnological exhibits" to a name, to a human being, deconstructing the idea of object which they were related to.
TABLE 1. Description of the Amerindians present at the British Guiana House with details about their activities and ages (Anonymous, 1886b: 313). ${ }^{5}$

\begin{tabular}{|l|l|}
\hline \multicolumn{2}{|c|}{ British Guiana - Red Indians } \\
\hline 1. Edward Seon & Interpreter and guide. \\
\hline 2. William Austin & Arecuna: hunter (42). \\
\hline 3. Christina Austin & $\begin{array}{l}\text { Wife of the above, Acawoio: } \\
\text { labourer (31). }\end{array}$ \\
\hline 4. Catherine Austin & Child of the above (5). \\
\hline 5. Anthony Gordon & $\begin{array}{l}\text { Macoosi: wood-cutter; reads and } \\
\text { writes in English (24). }\end{array}$ \\
\hline 6. Catherine \\
Matthews & $\begin{array}{l}\text { Aunt of Anthony: Acawoio: } \\
\text { labourer (32). }\end{array}$ \\
\hline 7. Maria Matthews & $\begin{array}{l}\text { Daughter of Catherine: Acawoio: } \\
\text { reads and writes a little (8). }\end{array}$ \\
\hline 8. Simeon Dance & Arecuna: labourer (26). \\
\hline 9. Rebecca Dance & $\begin{array}{l}\text { Wife of Simeon: Arecuna: field } \\
\text { labourer (24). }\end{array}$ \\
\hline 10. John Dance & Child of above: Arecuna (2). \\
\hline
\end{tabular}

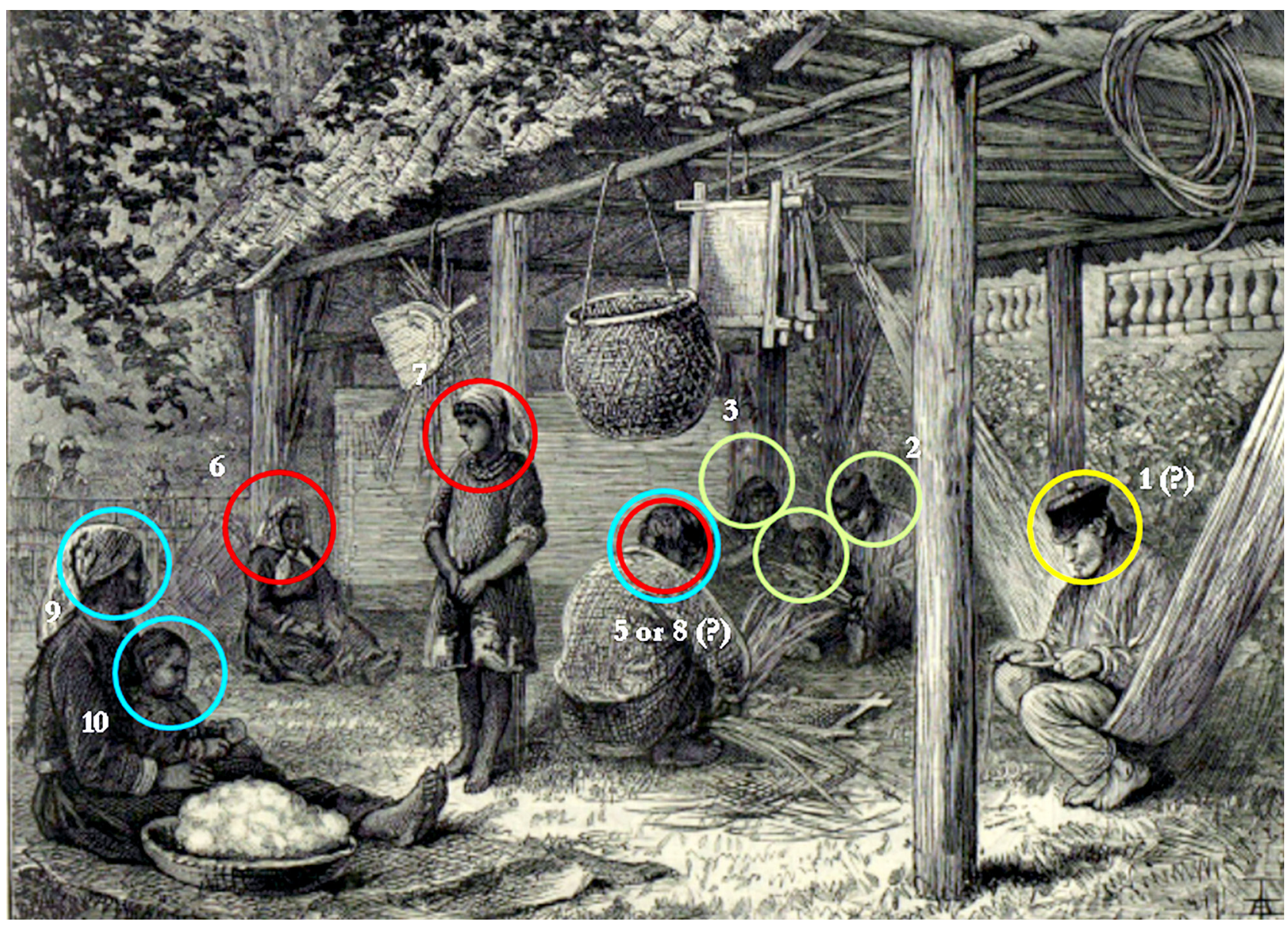

Figure 7. "Native House, British Guiana", image adapted from The Illustrated London News (1886: 337) (Legend: Blue circles - Dance family; Red circles - Mathews' and Gordon's family; Green circles - Austin's family; Yellow circle - unknown). 


\section{GLIMPSES OF THE BGC THROUGH THE ILLUSTRATED LONDON NEWS}

Looking through the illustrations of the newspapers in which the Colonial and Indian Exhibition 1886 is featured is almost like having a snapshot reflecting the connection between Britain and British Guiana through its products and wealth. The way those objects were on display also shows what kind of Guyanese objects and products interested Britain.

In the illustrations where the $\mathrm{BGC}$ is depicted, three Amerindian models are on display: two of them in the North and South entrances respectively and another at the ethnological stand (representing a woman with a baby) (Fig.1, 2 and 3). One of the models, probably the one at the south entrance, was described by the Illustrated London News as "the chocolate-coloured native, wearing a fish-bone necklace, who stands on guard, as it were, immediately to the left on entering, is a typical aboriginal." ${ }^{46}$ According to The Times, "the very perfectly modelled figures" of Amerindians "lent by the Crystal Palace, and regenerated by $\mathrm{Mr}$ im Thurn" were the attractions in the BGC that always had small groups around them. ${ }^{47}$ Similar model figures of Andaman islanders were also on display at the east entrance to the Indian Imperial Court in order to impress the crowds and attract more public (Wintle, 2009).

Besides the Amerindian model, the figure of the South Entrance (Fig. 2) has many interesting details including canoes, illustrations, curious visitors and a variety of plants - for example, palms at the entry of the court. According to The Times, the entrance of the British Guiana showed good taste in its sparing use of flags in contrast with other courts such as the West Indian Court. The Times adds that the decorations of the BGC "display unusual taste and artistic finish." ${ }^{48}$ Here, the displayed objects and the way they were exhibited not only symbolise the exotic but also invoke the idea of tropicality. The Amerindian model, the canoes, the illustrations and even the palms give the idea of "an alluring dream of opulence and exuberance" (Arnold, 1996). Although this may be the case, as Arnold suggests, there is also an ambivalence underneath this tropicality (Arnold, 1996: 142). This tropicality could also represent "an alien world of cruelty and disease, oppression and slavery" (Arnold, 1996: 142). Overall, the tropicality was the idea of the different, the alien world in terms of "climate, vegetation, people and disease", the experience of the white man "moving into an alien world" (Arnold, 1996: 143). It is also important to stress a point Arnold observes:

The tropics were not just perceived to be the site of an exotic, luxuriant nature, on the one hand, or wild beasts and deadly fevers, on the other. The tropics were also identified with the people who inhabited the equatorial regions (Arnold, 1996: 158).

The entrance to this small court was similar to a gate to the tropical world in which the model of the Amerindi- an was reinforcing this idea of tropicality. This was a reflection of all of these ideas of tropicality, which were converging together because of the experiences of naturalists and explorers, especially in the nineteenth century, into this "alien world."

This idea of tropicality was also reinforced through images and photographs. The BGC was described as a "fair show of maps, and an extremely interesting series of water-colour views of the colony." ${ }^{49}$ This is confirmed by the image in the Illustrated London News (Fig. 2) that shows illustrations on display, which according to the $O f$ ficial Catalogue were probably maps, plans, paintings, water-colour drawings and photographs (Anonymous, 1886a). Looking through the descriptions in the Special Catalogue, there were photographs "illustrative of British Guiana, its scenery and inhabitants" by C. Norton, a water-colour Sketch of Roraima by im Thurn and on the top of the entrance an illustration of the capital, Georgetown (Hawtayne, 1886: 18). Although im Thurn had an enormous interest in photography, it is important to note that for this exhibition, he only contributed with one watercolour sketch of Roraima and, interestingly, no photographs at all (Anonymous, 1886a). The only photos listed in the Official Catalogue were from C. Norton and Siza (Anonymous, 1886a). However, Kew received a photograph entitled British Guiana, Three Mile Trench of Victoria regia Lilies from this exhibition signed by B.R. Back. Nonetheless, this particular photograph is not listed in the Official Catalogue. This photo illustrates a very emblematic image of British Guiana by showing several Victoria regia distributed in one of the many canals of the colony. ${ }^{50}$ Schomburgk commented on this peculiar species: "What could better give an idea of the luxuriance and richness of vegetation in Guiana, than the splendid Victoria regia, the most beautiful specimen of flora in the western hemisphere?'(Schomburgk, 1840 cit. by Burnett, 2000).

\section{CONCLUSION}

Through the Illustrated London News, the reader was informed not only by text but also by the use of images. By doing so, the Colonial and Indian Exhibition, 1886 could transversely reach the population regardless of their social status, education or literacy level, encouraging the idea of popularization and nurturing the so aimed identity connected to the empire and reflecting the empire's desire for progress and industrialisation.

This exhibition also placed together unrelated peoples of different parts of the Empire not only physically but also psychologically, giving a sense of unity and belonging to the Empire (Greenhalgh, 1988). However, although there was this idea of unity of the empire, there was also the contrasting vision of a distant and tropical world which the colonies belonged to, a very different world from the "mother country".

In the particular case of the BGC, this feeling of tropicality was reinforced through the image of the gate, with the presence of exuberant palms, exotic photographs, as 
the case of the Victoria regia and models of Amerindians at the entrance of the court giving a sense of an "alien world". However, the models were not only used to decorate the court entrance, but also to attract the public. This happened with the Amerindian models and also with the Andaman Islanders figures, both representing small colonies that needed visibility at the exhibition (Wintle, 2009). In addition, the display of "living ethnological exhibits" at the British Guiana House reinforces not only the idea of the "alien world" but also clearly shows how the Amerindians were seen as objects at the exhibition. Benedict also proposes that there are many reasons for exhibiting people and objects that are not related to power so the display of people should be analysed even in theatrical terms. In other words, the setting, the scenario, the dresses, tools and objects are all of part of the theatrical setup (Benedict, 1994). The example of the "British Guiana House" clearly illustrates the purpose of these "native villages" whose function was "to show off the quaint, the savage, the exotic, to offer living proof of the onward march of imperial civilization" (Mackenzie, 2008), and to emphasise the "continuity of ethnic or cultural differences" (Benedict, 1994).

Another aspect to have into account is the symbolism behind the court gates, which were made with massive logs of wood, representing in a certain way the power and wealth of the colony. The gates were made of great logs of important species that were not only "leading economic woods of British Guiana" and wood of great quality which represented the ascendance of British commercial influence, but also represented the amount of investment and trade at the time. Besides their economic importance, they were also relevant for their medicinal properties, known by the Amerindians in the first place, which in turn could have the potential to contribute to progress in science, such as the study of certain chemicals.

The way the objects were displayed at the BGC may also reveal the power relations which were "disguised by amusements or displays of crafts", as Benedict said. He goes further by explaining that "every time we put some object on show in a museum or some person on show on a stage, or making a pot, power relations are being expressed". Besides this, im Thurn's objects collections also had the objective of preserving the objects that were disappearing and not being produced as before. Because of im Thurn's first-hand experience of British Guiana and its inhabitants, it is easily understood why he was invited to organise the Ethnological stand in this Colonial and Indian Exhibition and contribute with ethnological specimens. Although there was an imperialist nostalgia in his discourse, particularly in his book Among the Indians of Guiana, it appears that he was genuinely concerned about the loss of the knowledge of Amerindian craftwork. While im Thurn was in the British colony he had "considerable freedom to pursue his anthropological interests" although he struggled with his official role (Dalziell, 2007). As im Thurn lived for so many years in British Guiana, he developed an attachment for that "geographically remote British colony", which affected his commit- ments to the "imperial centre" (Dalziell, 2007). It is possible that his drive to exhibit some of the objects at the Exhibition in 1886 was not to display the Amerindian objects as a mere "curiosity". I instead suggest that im Thurn was in fact collecting and displaying the objects in order to salvage them, as if he wanted to give a contribution to the Amerindian culture by leaving a legacy of those Amerindian objects in the imperial metropolis. Besides this, im Thurn was also advertising the potential of the "neglected colony" and trying to ensure that British Guiana would not be forgotten.

What happened to the exhibited items it is not known for certain, however the correspondence between im Thurn and Kew reflects some examples of how the institutions obtained objects from exhibitions and at the same time explored the misunderstandings between the institutions and the collectors.

Besides the valuable woods mentioned previously, it is possible to infer through the exhibition, that British Guiana was also valued because of its gold and sugar. Although these last two could be seen as strengths of the colony, they also reflected its very own weaknesses. In the case of gold, it triggered disputes between British Guiana and Venezuela. In the case of sugar, although a leading commodity, its exportation was declining due to the rival sugar beet, that "was being subsidized by their own countries" making it a difficult situation for British Guiana to compete with (Rodney, 1981: 661).

In conclusion, the BGC, although small, was very rich in terms of exhibited items. It is this richness of raw materials and objects on display that, when cross referenced with newspapers and correspondence of the time allows the analysis of this British colony in the light of the epoch.

\section{ACKNOWLEDGEMENTS}

I am grateful to my $\mathrm{PhD}$ supervisors Dr Luciana Martins (Birkbeck College, University of London) and Christopher Mills (RBG, Kew). A special thanks to Paulette Allicock, Dr Mark Nesbitt (RBG, Kew), Dr Terry Roopnaraine for their support and guidance, Dr Maria Zozaya (CIDEHUS-UÉ) for revising the Spanish, Dr Maria de Fátima Nunes (Universidade de Évora, IHC-CEHFCiUÉ) and Miguel Soares for their kindness and contribution in revising this paper. The present article was financed by FCT (Fundação para a Ciência e a Tecnologia, reference SFRH/BD/45965/2008 and PEst-OE/HIS/ UI0613/2014, Portugal) and by the AHRC (Arts and Humanities Research Council, UK).

\section{NOTES}

1 The Times (London, England) [TT] "The Colonial and Indian Exhibition: British Guiana", Issue 31824, col A, 29 July 1886: 13 .

2 The Illustrated London News (London, England) [TILN] "Colonial Indian Exhibition: British Guiana, West Indies and British Honduras" (Supplement) Colonial Indian Exhibition, Issue 2475, 25 September 1886: 337-342. 
3 TT "The Colonial and Indian Exhibition", Issue 31742, col A, 24 April 1886: 7.

4 TILN, Issue 2475, 25 September 1886: 337-342.

5 Royal Botanic Gardens, Kew, London, UK [RBG, Kew], Directors Correspondence, KLDC11574, Letter from Everard F. [Ferdinand] im Thurn to [Sir William Thiselton-Dyer], from British Guiana Museum, Georgetown [Guyana], 5 November 1877, f. 293; In this letter im Thurn mentions that he was sending to Kew the prospectus for a local exhibition to be held in January [1888] and offers to send any specimens mentioned therein that Thiselton-Dyer desires.

6 TT "The Colonial and Indian Exhibition", Issue 31742, col A, 24 April 1886: 7.

7 TT, Issue 31824, 29 July 1886: 13.

8 TT "The Colonies", Issue 33621, col C, 25 April 1892: 4.

9 TT, Issue 31824, 29 July 1886: 13.

10 TT, Issue 31824, 29 July 1886: 13.

11 TT, Issue 33621, 25 April 1892: 4.

12 TT, Issue 31824, 29 July 1886: 13.

13 RBG, Kew, Directors Correspondence, KLDC11606, Letter from Everard F. im Thurn to Sir William Thiselton-Dyer, from Pomeroon River, British Guiana, 12 March 1887, f. 328.

14 RBG, Kew, Directors Correspondence, KLDC11590, Letter from Everard F. im Thurn to Sir Joseph Dalton Hooker, from Pomeroon River, British Guiana, 11 February 1885, f. 312.

15 RBG, Kew, Directors Correspondence, KLDC11590.

16 RBG, Kew, Directors Correspondence, KLDC 11590.

17 Nectandra rodioei R.H. Schomb. is a synonym and today's accepted name is Chlorocardium rodiei (R.H. Schomb.) Rohwer, H.G. Richt. \& van der Werff

18 The species is probably Hyeronima alchorneoides Allemão (Euphorbiaceae), which is a commercial timber used for canoes, floors and furniture (van Andel, 2000).

19 TT, Issue 31824, 29 July 1886: 13.

20 TILN, Issue 2475, 25 September 1886: 337-342.

21 TT, Issue 31824, 29 July 1886: 13.

22 TT, Issue 31824, 29 July 1886: 13.

23 Royal Botanic Gardens, Kew - Economic Botany Collections (EBC Cat. no. 45266).

24 As part of my $\mathrm{PhD}$ project, I made a fieldtrip to Guyana, in October 2010, in order to 'find' similar Amerindian objects to the ones collected by Everard im Thurn, as well as to understand if they were still using the same species described by im Thurn. During this expedition, several Amerindians were interviewed. Paulette Allicock (from the MRU - Makushi Research Unit) personal communication, Surama, Guyana, October 2010.

25 Nowadays, the Horniman Museum does not hold the items sent from Kew or Everard im Thurn.

26 TT, Issue 31824, 29 July 1886: 13.

27 TT, Issue 31824, 29 July 1886: 13.

28 TT, Issue 33621, 25 April 1892: 4.

29 TT, Issue 31824, 29 July 1886: 13.

30 TT, Issue 31824, 29 July 1886: 13.

31 TT, Issue 31824, 29 July 1886: 13.

32 Note attached to the basket sent to the British Museum (1960. Am10.67)

33 Notes attached to the objects at the British Museum.

34 Paulette Allicock (from the MRU - Makushi Research Unit) personal communication, Surama, Guyana, October 2010

35 Paulette Allicock (from the MRU - Makushi Research Unit) personal communication, Surama, Guyana, October 2010.

36 Paulette Allicock (from the MRU - Makushi Research Unit) personal communication, Surama, Guyana, October 2010.

37 The British Guiana house is marked as pink on the left side in the ground plan of the exhibition, as the illustration shows.

38 TT, Issue 31824, 29 July 1886: 13.

39 TT, Issue 31807, 9 July 1886: 7.

40 TT "The Queen at the Colonial Exhibition", Issue 31813, col A, 16 July 1886: 8

41 TT "The Queen at the Colonial Exhibition", Issue 31813, col A, 16 July 1886: 8

42 TT, Issue 31824, 29 July 1886: 13.
43 TILN, Issue 2475, 25 September 1886: 338.

44 TT, Issue 31824, 29 July 1886: 13.

45 TT, Issue 31807, 9 July 1886: 7

46 TILN, Issue 2475, 25 September 1886: 338.

47 TT, Issue 31824, 29 July 1886: 13; As the Great Exhibition of 1851 took place at Crystal Palace, there is the possibility the Amerindian models used in the 1851 exhibition were in fact the same that were on display at the British Guiana court in 1886.

48 TT "Court Circular, Windsor Castle, July 8", Issue 31807, col A, 9 July $1886: 7$

49 TT, Issue 31824, 29 July 1886: 13.

50 The accepted name is Victoria amazonica (Poepp.) J.C. Sowerby (Missouri Botanical Garden, 2011b).

51 Notes attached to the table: "These people had all been baptized in the Church of England Mission. They cultivate land, fish, and hunt, and are employed by wood-cutters." The figures between the parentheses denote the age.

\section{REFERENCES}

Aguirre, Robert (2004) "Introduction". In Informal Empire: Mexico and Central America in Victorian Culture. University of Minnesota Press, Minneapolis: 13-29.

Andel, T.R. van (2000) Non-timber Forest products of the NorthWest District of Guyana Part II: A field guide. Tropenbos-Guyana series 8B (Dissertation), Utrecht University, Georgetown, Guyana. http://dspace.library.uu.nl/handle/1874/1168. [accessed 17/February/2012].

Anonymous (1886a) Official Catalogue of the Colonial and Indian Exhibition. William Clowes \& Sons, London.

Anonymous (1886b) Report of the Royal Commission for the Colonial and Indian Exhibition. London.

Anonymous (1960) "Review of the Work of the Royal Botanic Gardens, Kew during 1958". Kew Bulletin, 14 (1): 1-28.

Arnold, David (1996) "Inventing Tropicality". In The problem of Nature: Environment, Culture and European Expansion. Blackwell Publishers, Oxford and Cambridge, Massachusetts: 141168.

Aspinall, Algernon (1933) "Sir Everard im Thurn: Born 1852: Died 7 October, 1932". Man. 33: 36-7.

Benedict, Burton (1991) "International Exhibitions and National Identity". Anthropology Today, 7 (3): 5-9. http://dx.doi. org/10.2307/3032792.

Benedict, Burton (1994) "Rituals of Representation: Ethnic Stereotypes and Colonized Peoples at World's Fairs". In Fair Representations: World's Fairs and the Modern World, edited by Rydell, Robert W.; Gwinn, Nancy. VU University Press, Amsterdam: 28-61.

Bennett, Tony (1988) "The Exhibitionary Complex". New formations, (4): 73-102

Blanchard, Pascal (2008) "Human Zoos: Science and Spectacle in the Age of Colonial Empires". In Human Zoos: Science and Spectacle in the Age of Colonial Empires, edited by Blanchard, Pascal; Bancel, Nicolas; Boëtsch, Gilles; et al. Liverpool University Press, Liverpool: 1-49.

Blanchard, Pascal; Gilles Boëtsch and Nanette Jacomijn Snoep (2011) "Exhibitions-L'invention du sauvage". Musée du Quai Branly, Actes Sud, Paris.

Bravo, Michael T. (1996) "Ethnological encounters". In Cultures of Natural History edited by Nicholas Jardine; James A. Secord and E.C. Spary. Cambridge University Press, Cambridge: 338357.

Burnett, D. Graham (2000) "Marks on the Land: Landmarks, Aesthetics, and the Image of the Colony". In Masters of All They Surveyed: Exploration, Geography, and a British El Dorado. University of Chicago Press, Chicago.

Çelik, Zeynep; Kinney, Leila (1990) "Ethnography and Exhibitionism at the Expositions Universelles". Assemblage, December (13): 34-59.

Cundall, F. (1886) "Reminiscences of the Colonial and Indian Exhibition". The Royal Commission, London. 
Dalziell, Rosamund (2002) “'A Tramp with Redskins': A British Colonial Administrator's Cross-Cultural Encounters”. In Selves Crossing Cultures: Autobiography and Globalisation. Australian Scholarly Publishing, Kew, Victoria: 89-103.

Dalziell, Rosamund (2007) "Everard im Thurn in British Guiana and the Western Pacific". In Writing, travel, and empire: in the margins of anthropology edited by Hulme, Peter; McDougall, Russell. I.B. Tauris, New York: 97-118.

Dutta, Arindam (1997) "The Politics of Display: India 1886 and 1986". Journal of Arts and Ideas, 30-31: 115-145. http://dsal. uchicago.edu/books/artsandideas/pager.html?objectid=HN681. S597_30-31_117.gif. [accessed 2/October/2015].

Fabian, Johannes (1983) Time and the Other, How Anthropology makes its object. Columbia University Press, New York.

Greenhalgh, Paul (1988) "Human showcases". In Ephemeral vistas: The Expositions Universelles, Great Exhibitions and World's Fairs, 1851-1939. Manchester University Press, Manchester: 82-111.

Gruber, Jacob W. (1970) "Ethnographic Salvage and the Shaping of Anthropology". American Anthropologist, 72 (6): 1289-1299.

Hawtayne, George H. (1884) "Our Representation at the International Colonial Exhibition of 1886". Timehri, The Journal of the Royal Agricultural \& Commercial Society of British Guiana, 3: 90-96.

Hawtayne, George H. (1886) Colonial and Indian Exhibition, 1886, Special Catalogue of Exhibits in British Guiana Court, with Introductory notes by G.H. Hawtayne, F.R.G.S., C.M.Z.S.”. William Clowes \& Sons, London.

Hawtayne, George H. (1887) "The Official Reports on the Colonial Section of the Exhibition 1886". Timehri, The Journal of the Royal Agricultural \& Commercial Society of British Guiana (New Series), 1: 1-34.

Im Thurn, Everard F. (1883) Among the Indians of Guiana: being Sketches Chiefly Anthropologic from the Interior of British Guiana. Kegan Paul, Trench \& Co, London.

Im Thurn, Everard F. (1884) "A Difficulty of Botanical Collectors". Timehri, The Journal of the Royal Agricultural \& Commercial Society of British Guiana, 3: 162-164.

Im Thurn, Everard F. (1885) "A Difficulty of Botanical Collectors". Timehri, The Journal of the Royal Agricultural \& Commercial Society of British Guiana, 4: 132-133.

J. R. J. (1887) "Notes on Articles Contributed to the Museums of the Royal Gardens, Kew, from the Colonial and Indian Exhibition, 1886". Bulletin of Miscellaneous Information (Royal Gardens, Kew), 9: 4-21.

Levell, Nicky (2000) "The Colonial and Indian Exhibition of 1886: An Imperial Vision". In Oriental Visions: Exhibitions, Travel, and Collecting in the Victorian Age, The Horniman Museum and Gardens, London \& Museu Antropológico de Coimbra. London and Coimbra: 63-111.

Mackenzie, John (2008) "The Imperial Exhibitions of Great Britain”. In Human Zoos: Science and Spectacle in the Age of Colonial Empires, edited by Blanchard, Pascal; Bancel, Nicolas; Boëtsch, Gilles; Deroo, Éric; Lemaire, Sandrine and Forsdick, Charles. Liverpool University Press, Liverpool: 259-268.

Mathur, Saloni (2000) "Living Ethnological Exhibits: The Case of 1886". Cultural Anthropology, 15 (4): 492-524.

Mathur, Saloni (2007a) India by Design: Colonial History and Cultural Display. University of California Press.

Mathur, Saloni (2007b) “"To Visit the Queen': On Display at the Colonial and Indian Exhibition of 1886". In India by Design: Colonial History and Cultural Display. University California Press, Berkeley, Los Angeles and London: 52-79.

Missouri Botanical Garden (2011a) "Nectandra rodioei". Missouri Botanical Garden. http://www.tropicos.org/ [accessed 21/September/2011].

Missouri Botanical Garden (2011b) "Tropicos.org". Missouri Botanical Garden. http://www.tropicos.org/ [accessed 30/September/2011].

Perkins, H. I. (1885) "Notes on a Journey to Mount Roraima, British Guiana". Proceedings of the Royal Geographical Society and Monthly Record of Geography, New Monthly Series, 7 (8): 522-534.

Qureshi, Sadiah (2011) Peoples on Parade: Exhibitions, Empire, and Anthropology in Nineteenth-Century Britain. University of Chicago Press, Chicago, IL.

Rivière, Peter (2010) "South American Tropical Forest Material". Anthropology and World Archaeology, University of Oxford. http://www.prm.ox.ac.uk/South_America.html. [accessed 10/ May/2011].

Rodney, Walter (1981) "Plantation Society in Guyana". Review (Fernand Braudel Center), 4 (4): 643-666.

Rosaldo, Renato (1989) "Imperialist Nostalgia". Representations, 26: $107-122$.

Roth, Walter E. (1924) An Introductory Study of the Arts, Crafts, and Customs of the Guiana Indians, Thirty-Eight Annual Report of the Bureau of American Ethnology 1916-17. Smithsonian Institution, Washington.

Schomburgk, Robert Herman (1840) A Description of British Guiana, Geographical and Statistical. Simpkin, Marshall, London.

Wintle, Claire (2009) "Model Subjects: Representations of the Andaman Islands at the Colonial and Indian Exhibition, 1886". History Workshop Journal, 67 (1): 194-207. 